\title{
Determinants of Financial Distress in Case of Insurance Companies in Ethiopia
}

\author{
Enyew Mulu Zelie \\ Lecturer, Department of Accounting and Finance, Mekdela Amba University, Ethiopia
}

\begin{abstract}
The financial health status of business firms and the effect of firm characteristics on it are taught to be one of the very important issues in the current business environment. This study empirically examines the effect of internal factors (i.e., Profitability, Liquidity, Efficiency, Leverage and firm size) on the financial distress condition of insurance companies in Ethiopia. The study is based on a ten year panel data ranging from 2009 to $2018 \mathrm{GC}$, obtained from a sample of nine insurance companies. The study employed the Altman's Z"-score model to measure the financial health condition of insurance companies under study, and the pooled OLS regression analysis to estimate the effect of determinant variables on financial distress. The study concluded that the profitability and liquidity levels of insurance companies have a statistically significant positive effect on their financial distress condition. Whereas, leverage has a statistically significant negative effect on the financial distress condition of insurance companies. Efficiency and firm size have no statistically significant effect on the financial health condition of insurance companies.
\end{abstract}

Keywords: Altman's Z"-Score, Financial distress, Pooled OLS.

DOI: $10.7176 / \mathrm{RJFA} / 10-15-05$

Publication date: August $31^{\text {st }} 2019$

\section{Introduction}

Financial distress is a condition in which a company does not have the capacity to fulfill its obligations, which leads to either restructuring or bankruptcy (Andrade \& Kaplan 1998). It is "the likelihood of bankruptcy, which depends on the level of liquid assets as well as the availability of credit" (Hendel, 1996). "Financial distress is a situation where a firm's operating cash flows are insufficient to cover current obligations, such as trade credits or interest payments, and the firm is obliged to take remedial action" (Wruck, 1990).

Financial distress can be caused by many factors such as, endogenous risks, miss-management, high leverage level, and an inefficient operating structures, low level of liquidity and negative cash flows (Andrade and Kaplan, 1998; Asquith et al., 1994; Theodossiou et al., 1996, Whitaker, 1999, Outecheva, 2007).

Firms failing under financial distress will face a variety of problems, such as dividend reductions, losses, plant closings, layoffs, reduced stock prices, CEO resignations, insufficient cash inflows to pay maturing debt \& contract renewal problems, difficulty in getting access to capital, lose customers, . (Charalambakis, Espenlaub \& Garrett, 2008; Purnanandam, 2007)

\subsection{Research Problem}

It is obvious that the insurance industry is one of the most important elements of the financial sector as well as the whole economy of a nation. A country's economy will be adversely affected by the failure of the insurance industry (International Accounting Standards Board, 2007). Insurance is the umbrella of all other sectors of an economy, which creates favorable operating climate by offering protections against possible losses of many kind. Insurances are also important sources of funds through their pooling system (Rand, 2004).

However, the failure of an insurance firm may lead to economic crisis. When companies become financially distressed, they will have an effect on the economy and negatively affect the economic stability of other sectors in a country (Kana, 2004). Since the operations of insurance companies are highly integrated with almost all other sectors of the economy, their failure can be easily spread to them. So it is very crucial to investigate the factors that can cause financial distress to the insurance business and there should be a continuous assessment of their financial and operational conditions.

\subsection{Research Objectives}

The general objective of this study was to examine the factors that determine financial distress in case of insurance companies in Ethiopia.

The specific objectives of the study were;

1. To examine the effect of profitability on financial distress condition.

2. To examine the effect of liquidity on financial distress condition.

3. To examine the effect of efficiency on financial distress condition.

4. To examine the effect of leverage on financial distress condition.

5. To examine the effect of firm size on financial distress condition. 


\section{Research Hypotheses}

1. Ha1: Profitability has a statistically significant effect on financial distress condition of Ethiopian insurance companies.

2. Ha2: Liquidity has a statistically significant effect on financial distress condition of Ethiopian insurance companies.

3. Ha3: Efficiency has a statistically significant effect on financial distress condition of Ethiopian insurance companies.

4. Ha4: Leverage has a statistically significant negative effect on financial distress condition of Ethiopian insurance companies.

5. Ha5: Firm size has a statistically significant positive effect on financial distress condition of Ethiopian insurance companies.

\section{Review of Related Literature}

\subsection{Meaning of Financial Distress}

Financial distress is one of the major causes of business failure. It can be defined as a condition of being in severe financial difficulties, especially being close to bankruptcy. The inability to meet or having difficulty in paying off its financial obligations to its creditors (Chang-e, 2006). Financial is the likelihood of bankruptcy, which depends on the level of liquid assets as well as on the availability of credit (Hendel, 1996). Financial distress is a situation where a firm's operating cash flows are insufficient to cover current obligations, such as trade credits or interest payments, and the firm is obliged to take remedial action (Wruck, 1990).

According to Baldwin and Scott (1983), when a firm's business worsens to the point where it cannot pay off its financial obligations, the firm is said to be financially distressed. They have suggested that the first signals of financial distress are typically violations of the terms of debt covenants and omission or decrease of dividends payments. Financial distress manifests through events such as; bond default, bankruptcy, bank account was overdrawn, or default of a preferred stock dividend (Beaver, 1966).

\subsection{Theories of Financial Distress}

\section{Liquid Asset Theory}

This theory is based on the concept that net cash flows relative to current liabilities should be the primary standard to be used to describe a company's financial distress condition. Firms which have positive cash flows are able to increase their capital and borrow from the capital market, whereas firms which have negative or inadequate cash inflow are unable to borrow from the capital market. Therefore they face the risk of default. According to this theory, a firm is anticipated to go bankrupt whenever the current year's profit or net cash flow is negative or less than the level of debt obligations (Scott, 1981). This situation is called technical insolvency.

\section{Liquidity and Profitability Theory}

According to this theory when the firm's liquidity and profitability indicators are good, it is considered as healthy and vice versa. A positive and high level of these two indicators shows a lower risk of bankruptcy. This theory suggests that a firm can fail even though its profitability is good. If the firm's growth rate is significantly greater than the internal rate of return, its revenue flow can be inadequate to finance expenditures and the firm is unable to pay its obligations if it is highly indebted. The firm's profitability should be greater than the company's growth rate.

\section{Balance Sheet Decomposition Measure (Entropy Theory)}

One way of identifying firms' financial distress is a cautious look at the major changes happening in their balance sheets (Aziz \& Dar, 2006). If a firm's balance sheet shows significant changes in their composition of assets and liabilities over a reasonable period of time, it is more likely that the firms are unable to maintain the equilibrium state. Since these changes are likely to become uncontrollable in future, we can anticipate financial distress in these firms (Monti \& Moriano, 2010).

\section{Cash Management Theory}

The management of cash balances is the most important concern of each firm. This is because it is challenging to predict cash flows precisely, particularly the inflows, and there is no perfect concurrence between cash inflows and outflows. An imbalance between cash inflows and outflows would signal the failure of cash management function of the firm, which may eventually cause financial distress to the firm and, hence, business failure (Aziz \& Dar, 2006).

\subsection{Empirical Literature}

Andualem, (2011) have conducted a research entitled "Financial Distress and Its Determinants in Selected Beverage and Metal Manufacturing Firms in Ethiopia". The study found that firm age, profitability, firm efficiency and liquidity have positive and significant influences on financial distress. Whereas, leverage has a statistically significant negative effect on financial distress of the beverage industry. 
Ephrem, (2015) examined the determinants of financial distress conditions of private commercial banks in Ethiopia and its findings indicate that capital to loan ratio, net interest income to total revenue ratio have statistically significant and positive effect on the financial health condition of banks. On the other hand, nonperforming loan ratio has a statically significant negative influence on the financial health of the banks.

Cheluget, (2014) have studied the determinants of financial distress in insurance companies in Kenya using ZETA score as a proxy for measuring financial distress. The study concluded that profitability, liquidity, efficiency, and leverage have significant positive effect on financial distress of insurance companies in Kenya.

\section{Research Design and Methodology}

This study is mainly explanatory/casual type since it is aimed at explaining the causal relationship between financial distress and factors that affect it. In addition, the study adopted the quantitative research approach. From the total population of 17 insurance companies in the country, only 9 of them have the required 10 year data. So the researcher took these all as a sample. The study used secondary data which includes the annual financial reports, mainly balance sheet and income statement of insurance companies under study.

\section{Data Analysis Methods}

Altman's Z-score model was used to estimate the financial distress condition of insurance companies. Altman has revised his bankruptcy prediction model and developed a new Z-score model which can be applied for predicting the financial distress condition of non-manufacturing firms. The new Z-Score model is; $Z^{\prime \prime}=6.56 \mathrm{X} 1+3.26 \mathrm{X} 2+6.72 \mathrm{X} 3+1.05 \mathrm{X} 4$

Where;

$Z^{\prime \prime}=$ Overall index of the financial distress measure of financial institutions

$$
\mathrm{X}_{1}=\frac{\text { Working capital }}{\text { Total assets }}
$$

This is a measure of the net liquid assets of the firm relative to the total Assets.

$$
\mathrm{X}_{2}=\frac{\text { Retained Earnings }}{\text { Total assets }}
$$

This is a measure of cumulative profitability over time. According to Altman (2000), the age of a firm is implicitly considered in this ratio.

$$
=\frac{\text { Earnings Before Interest and Taxes (EBIT) }}{\text { Total Assets }}
$$

This ratio measures the true productivity of the company's total assets, independent of any tax or leverage effects. Since a firm's ultimate existence is based on the earning power of its assets, this ratio appears to be mostly appropriate for studies dealing with corporate failure.

\section{$\mathrm{X}_{4}=\frac{\text { Book Value of Equity }(\mathrm{BVE})}{\text { Total Debt }}$}

This measure shows how much the firm's assets can decline in value before the liabilities exceed the assets and the firm becomes insolvent.

In addition, in order to test the numerical relationship between the dependent variable (i.e. financial distress condition) and the independent variables (i.e. profitability, liquidity, leverage, efficiency and firm size), the pooled OLS regression analysis is used.

\section{Findings and Results}

\subsection{Post Estimation Tests}

\subsubsection{Normality Graph}

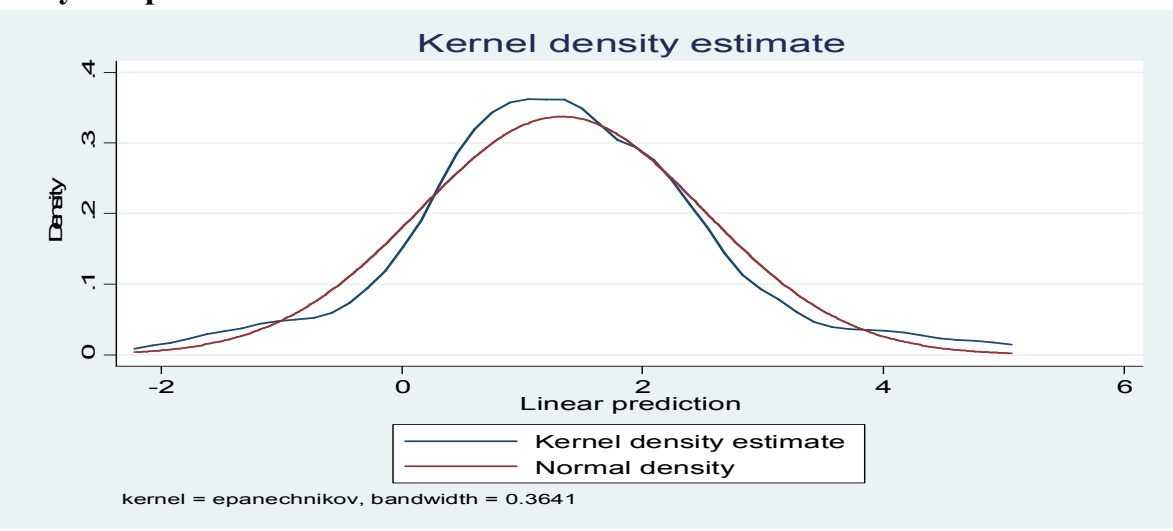




\subsubsection{Heteroscedasticity Test}

Breusch-Pagan / Cook-Weisberg test for heteroscedasticity

Ho: Constant variance

Variables: fitted values of $\mathbf{Z}$ '-Score

chi2(1) $=0.81$

Prob $>$ chi2 $=0.3672$

Table 4.1. Breusch-Pagan / Cook-Weisberg Test for Heteroscedasticity

As shown in table 4.1, the P-value for Breusch-Pagan heteroscedasticity test is 0.3672 , which is greater than 0.05 . So there is no evidence for the existence of heteroscedasticity problem in the data set.

\subsubsection{Multicollinearity Test}

\begin{tabular}{|l|l|l|}
\hline Variable & VIF & 1/VIF \\
\hline Prof & 1.85 & 0.540786 \\
Eff & 1.56 & 0.639515 \\
Lnsize & 1.49 & 0.670366 \\
Lev & 1.44 & 0.693860 \\
Liq & 1.32 & 0.755410 \\
\hline Mean VIF & 1.53 & \\
\hline
\end{tabular}

Table 4.2. VIF Test for Multicollinearity

As indicated in table 4.13, the value of mean VIF is lower than 10. The individual value of VIF for each independent variables are lower than 10 and the value of $1 /$ VIF are greater than 0.10 . So, there is no evidence for the existence of Multicollinearity problem in the data set.

\subsubsection{Test for Autocorrelation: The Durbin - Watson (DW) Test}

Durbin-Watson d-statistic( 6,90$)$

Table 4.3. The Durbin - Watson (DW) Test for autocorrelation

As shown in table 4.14, the value of Durbin-Watson (DW) test statistic is 1.669873, which is closer to 2. Hence, there is no evidence for the existence of autocorrelation problem in the data set.

\subsection{Pooled OLS Regression Analysis Results and Discussion}

In this section, the result of the pooled OLS regression analysis that has been estimated to determine the relationship between the dependent variable (financial distress), and the independent variables (profitability, liquidity, efficiency, leverage and firm size) is presented. The result of model specification tests (The Hausman Test for Fixed Vs. Random Effect models, and Breusch-Pagan Lagrange multiplier (LM) test for Random Effects Vs. Pooled OLS Regression) shows that the pooled OLS estimation is the best fit model for the data set.

\begin{tabular}{|c|c|c|c|c|c|c|}
\hline Source & SS & DF & \multicolumn{2}{|c|}{ MS } & \multirow{3}{*}{\multicolumn{2}{|c|}{$\begin{array}{l}\text { Number of Obs. }=90 \\
\text { F }(5,84)=536.02 \\
\text { Prob. }>\text { F }=0.0000 \\
\text { R-Squared }=\mathbf{0 . 9 6 9 6} \\
\text { Adj. R-Squared }=0.9678 \\
\text { Root MSE }=0.21557\end{array}$}} \\
\hline $\begin{array}{l}\text { Model } \\
\text { Residual }\end{array}$ & $\begin{array}{l}124.549463 \\
3.90367184\end{array}$ & $\begin{array}{l}5 \\
84\end{array}$ & \multicolumn{2}{|c|}{$\begin{array}{l}24.9098926 \\
0.046472284\end{array}$} & & \\
\hline Total & 128.453135 & 89 & 1.4432 & & & \\
\hline Z"-Score & Coef. & Std. Err & $\mathrm{t}$ & $\mathrm{P}>|\mathrm{t}|$ & \multicolumn{2}{|c|}{ (95\% Conf. Interval) } \\
\hline $\begin{array}{l}\text { Prof } \\
\text { Liq } \\
\text { Eff } \\
\text { Lev } \\
\text { Lnsize } \\
\text { _Cons }\end{array}$ & $\begin{array}{l}7.66106 \\
4.178078 \\
0.0993422 \\
-2.122484 \\
0.0476147 \\
-3.055317\end{array}$ & $\begin{array}{l}0.5546163 \\
0.1246508 \\
0.3150965 \\
0.3332829 \\
0.0287177 \\
0.5253666\end{array}$ & $\begin{array}{l}13.81 \\
33.52 \\
0.32 \\
-6.37 \\
1.66 \\
-5.82\end{array}$ & $\begin{array}{l}0.000 \\
0.000 \\
0.753 \\
0.000 \\
0.101 \\
0.000\end{array}$ & $\begin{array}{l}6.558144 \\
3.930196 \\
-0.5272618 \\
-2.785254 \\
-0.0094937 \\
-4.100066\end{array}$ & $\begin{array}{l}8.763975 \\
4.42596 \\
0.7259461 \\
-1.459715 \\
0.1047231 \\
-2.010568\end{array}$ \\
\hline
\end{tabular}

Table 4.4. Pooled OLS Regression Analysis

The overall P-value of the model is less than 0.05 , which indicates the overall significance of the explanatory variables used in this study in explaining the changes in the financial health condition of insurance companies under study. The result of $\mathrm{R}^{2}$ shows that about $96.96 \%$ of the variation in Z"- the score is explained by the explanatory variables and the models used in this study is well fitted to the data. The value of adjusted $\mathrm{R}^{2}$ is very close to the $\mathrm{R}^{2}$, which indicates there is a very honest statistical association between the explanatory variables and the explained variable. The value of F-statistic of the model is 536.02, which shows the overall significance of the 
explanatory variables and the model used in the study sufficiently describes the data.

Referring to the P-value and t-statistic of each explanatory variables in table 4.4, profitability (Prof), liquidity (Liq) and leverage (Lev) have a statistically significant effects on the financial distress, at 1\% significance level. So the null hypotheses formulated for these variables is rejected, and instead we accept the alternative hypotheses. Whereas, efficiency (Eff) and firm size (LnSize) have no significant effects on financial distress condition of insurance companies. So we accept the null hypotheses for these variables.

\section{Conclusion and Recommendations}

\subsection{Conclusions}

This study empirically examines the determinants of financial distress in selected insurance companies in Ethiopia. The study used a ten-year financial data ranging from 2009 to 2018, from a sample of nine insurance companies. Based on the findings obtained from the pooled OLS regression analysis, the following conclusions are made.

* Profitability of insurance companies measured by return on capital employed has a statistically significant positive effect on financial distress condition of Ethiopian insurance companies. This implies that the higher the level of profitability, the better financial healthiness, and stability.

* Liquidity of insurance companies measured by the current ratio has a statistically significant positive effect on financial distress condition of Ethiopian insurance companies. This indicates that, when the ratio of current assets to current liabilities increases, the financial health of insurance companies will be improved.

* The Efficiency of insurance companies measured by the total assets turnover ratio has no a statistically significant effect on the financial health condition of Ethiopian insurance companies.

* Leverage level of insurance companies measured by the debt ratio has a statistically significant negative effect on financial distress condition of Ethiopian insurance companies. This means the use of higher debt financing will negatively affect the financial healthiness of Ethiopian insurance companies.

* The size of insurance companies measured by the natural logarithm of total assets has no a statistically significant effect on financial distress condition of Ethiopian insurance companies.

\subsection{Recommendations}

For further researchers on this topic, we recommend them to consider macroeconomic variables. In addition, it is advisable to investigate insurance companies that were not covered under this study.

\section{References}

Altman, E., \& Hotchkiss, E. (2005). Corporate financial distress and bankruptcy: Predict and avoid and invest in distressed debt.

Andrade, G., \& Kaplan, S. (1998). How costly is financial (not economic) distress? Evidence from highly leveraged transactions that become distressed: Journal of Finance, 53(5), 1443-1493.

Andualem, U. B. (2011). Determinants of financial distress in selected beverage and metal industries in Ethiopia (MSc. thesis).

Asquith, P., Grtner, R., \& Shefstein (1994). Anatomy of financial distress: An explanation of Junk Bonds Issuer. The Quarterly Journal of Economics, 625-658.

Aziz, M., \& Dar, H. (2006). Predicting corporate financial distress: Whither do we stand? Corporate governance, $6(1)$.

Baldwin, C., \& Scott, M. (1983). The resolution of claims in financial distress: the case of Massey Ferguson, Journal of Finance, 38.

Barrese, James and Jack M. Nelson (1991). Guaranty Fund Assessments: Who Bears the Burden?, Presentation at the American Risk and Insurance Association meeting. San Diego.

Bever, W. (1966). Financial ratio as predictor of failure: Empirical research in Accounting. Journal of Accounting Research, 71-111.

Brigham, F. E. (2011). Financial management theory and practice. USA: South-Western Cengage Learning.

Brooks, C. (2008). Introductory Econometrics for Finance, 2nd ed. Cambridge University, New Work.

Chang-e, S. (2006). The causes and salvation ways of financial distress companies: An empirical research on the listed companies in China. Bejing University.

Charalambakis, Espenlaub, \& Garrett (2008). Leverage dynamics, the endogeniety of corporate tax Status and financial distress costs, and capital structure, Working Paper.

Cheluget, K. (2014). Determinants of financial distress in insurance companies in Kenya (Doctorate Dissertation).

Edward I. Altman (1968). Financial Ratios, Discriminant Analysis and the Prediction of Corporate Bankruptcy. The Journal of Finance, Vol. 23, No. 4.

Ephrem, G. (2015). Determinants of financial distress conditions of commercial banks in Ethiopia: A case study of selected private commercial banks. Journal of Poverty, Investment and Development, 13. 
Ephrem, G., \& Nidu (2015). Assessment of financial distress conditions of commercial Banks in Ethiopia: A case study of selected private commercial banks. Journal of Poverty, Investment and Development, 12.

Espen, S. (1999). Assessment of credit risk in Norwegian business sector (Thesis, The University of Bergen, Bergen, Norway).

Gestel, T., Baesens, B., Suykens, J., \& Willekens, M. (2006). Bayesian kernel based classification for financial distress detection. European Journal of Operational Research, 172(3), 979-1003.

Hailu Zeleke (2007). Insurance in Ethiopia: Historical Development, Present Status and Future Challenges. Addis Ababa: Master Printing Press.

Hambrick, D., \& Aveni, D. R. (1988). Large Corporate Failure as Downward Spiral. Administrative Science Quarterly, 33, 1-23.

Hendel, I. (1996). Competition under financial distress. The Journal of Industrial, 54(3), 309-324.

Hifza Malik, (2011). Determinants of Insurance Companies Profitability: An Analysis of Insurance Sector of Pakistan. Academic Research International, Volume 1, Issue 3

IASB, (2007). International Accounting Standard Board.'

James M. Carson (1992). Financial distress in the life insurance industry: an empirical examination. Illinois State University, USA.

Jeffrey M. Wooldridge (2012), Introductorty Economics. $5^{\text {th }}$ edition: A Modern Approach. Michigan State University, Nelson Education, Ltd.s

Lau, A. H. (1987). A five-state financial distress predication model. Journal of Accounting Research, 25.

Monti, E. N., \& Moriano, G. R. (2010). A statistical analysis to predict financial distress. Journal Service \& Management.

Nyunja, F. (2011). Credit Risk. KASNEB News line, January-march (1).

Ogawa, K. (2003). Financial distress and employment. The Japanese case in the 90s, Working Paper 9646, Massachusetts Avenue, Cambridge, MA 02138.

Outecheva (2007). Corporate financial distress. An empirical analysis of distress risk. The University of St.Gallen, Switzerland.

Peter R. Haiss and Kjell Sumegi (2008). The Relationship of Insurance and Economic Growth: A Theoretical and Empirical Analysis. Journal of Economics and Economic Policy, Vol.35

Pranowo, K. N., Azam, Achsani, A. H., Manurung, and Nurya (2010). Determinants of corporate financial distress in an emerging market economy.

Purnanandam \& Amiyatosh (2004). Do banks hedge in response to the financial distress costs? Ann Arbor, MI 48109, University of Michigan Business School.

R. Charles Moyer, J. R. (2006). Contemporary Financial Management.

Scott, J. (1981). The probability of bankruptcy: a comparison of empirical predictions and theoretical models. Journal of Banking and Finance. 5.

Theodossiou, Ioannis, Euan Phimister, and Richard Upward (1996). Factors that affect the decision to acquire a financially distressed Firm in US. University of Macedonia.

Trieschmann, James S., and George E. Pinches (1973). A Multivariate Model for Predicting Financially Distressed P-L Insurers. Journal of Risk and Insurance, 40:327-338.

Ward and Zurbruegg, W. D. (2000). Does Insurance Promote Economic Growth? Evidence from OECD Countries. The Journal of Risk and Insurance, pp.489-506.

Weitzel, W. and Jonsson, E. (2009), Decline in organizations: A Literature Integration and Extension, Administrative Science Quarterly, 34, 91-109.

Westgaard, S., \& Wijst, N. V. (2001). Default probabilities in a corporate bank portfolio: A Logistic Model Approach." European Journal of Operational Research, 135(2).

Whitaker, R. (1999). The early stages of financial distress. Journal of Economics and Finance. 23(2), 123-133.

Wruck, K. (1990). Financial distress, reorganization, and organizational efficiency. Journal of Financial Economics, 27, 419-444.

Yohannes, T. (2014). The determinants of financial distress in the case of manufacturing share companies in Addis Ababa, Ethiopia (MSc. Thesis). 